\title{
Nocardia globerula NHB-2 nitrilase catalysed biotransformation of 4-cyanopyridine to isonicotinic acid
}

\author{
Nitya Nand Sharma ${ }^{1,2}$, Monica Sharma ${ }^{1,3}$ and Tek Chand Bhalla*
}

\begin{abstract}
Isonicotinic acid (INA) is an important pyridine derivative used in the manufacture of isoniazid (antituberculosatic drug) and other pharmaceutically important drugs. Nitrilase catalysed processes for the synthesis of pharmaceutically important acids from their corresponding nitriles are promising alternative over the cumbersome, hazardous, and energy demanding chemical processes. Nitrilase of Nocardia globerula NHB-2 (NitNHB2) is expressed in presence of isobutyronitrile in the growth medium (1.0\% glucose, $0.5 \%$ peptone, $0.3 \%$ beef extract, and $0.1 \%$ yeast extract, $\mathrm{pH} 7.5)$. NitNHB2 hydrolyses 4-cyanopyridine (4-CP) to INA without accumulation of isonicotinamide, which is common in the reaction catalysed via fungal nitrilases. The NitNHB2 suffers from substrate inhibition effect and hydrolysing activity up to $250 \mathrm{mM}$ 4-CP was recorded. Complete conversion of $200 \mathrm{mM}$ 4-CP to INA was achieved in 40 min using resting cell concentration corresponding to $10 \mathrm{U} \mathrm{mL} L^{-1}$ nitrilase activity in the reaction. Substrate inhibition effect in the fed batch reaction (200 mM substrate feed/40min) led to formation of only 729 mM INA. In a fed batch reaction (100 mM 4-CP/20min), substrate inhibition effect was encountered after $7^{\text {th }}$ feed and a total of $958 \mathrm{mM}$ INA was produced in $400 \mathrm{~min}$. The fed batch reaction scaled up to $1 \mathrm{~L}$ and $100 \%$ hydrolysis of $700 \mathrm{mM}$ of $4-\mathrm{CP}$ to INA at $35^{\circ} \mathrm{C}$ achieved in $140 \mathrm{~min}$. The rate of INA production was $21.1 \mathrm{~g} \mathrm{~h}^{-1} \mathrm{mgDCw}^{-1}$. This is the fastest biotransformation process ever reported for INA production with time and space productivity of $36 \mathrm{~g} \mathrm{~L}^{-1} \mathrm{~h}^{-1}$ using a bacterial nitrilase.
\end{abstract}

Keywords: 4-Cyanopyridine, Isonicotinic acid, Isobutyronitrile, Bacterial nitrilase, Biotransformation, Substrate inhibition, Fed batch

\section{Introduction}

Isonicotinic acid (INA) is an important pyridine derivative used in the synthesis of antituberculostatic drug isoniazid (isonicotinic acid hydrazide). The conventional chemical process which utilizes 4-cyanopyridine and hydrazine hydrate as reactants is hazardous, energy demanding and expensive (Yadav et al. 2005). Recently ethyl isonicotinate (synthesized from INA) has been used for chemoenzymatic synthesis of isoniazid by lipase-catalyzed transesterification in non-aqueous medium onto hydrazine hydrate (Yadav et al. 2005). Isoniazid also inhibits the developmental stages of malarial parasites (Plasmodium gallinaceum and P. berghei) in mosquito (Arai et al. 2004). INA is

\footnotetext{
* Correspondence: bhallatc@rediffmail.com

'Department of Biotechnology, Himachal Pradesh University, Summer Hill, Shimla 171005, India

Full list of author information is available at the end of the article
}

used for the synthesis of inabenfide, a plant growth regulator. Terefenadine, an antihistamine and nialamide, an antidepressant are also derived from INA (Scriven et al. 1998). INA also finds application as an anticorrosion reagent, electroplating additive, and photosensitive resin stabilizer (Wu et al. 1991).

INA is manufactured through several chemical methods including potassium permanganate oxidation, air oxidation, and ozone oxidation (Qiao et al. 2000). An alternative method is the electrolytic method using 4-methylpyridine as the raw material and aqueous sulphuric acid solution as the supporting electrolytes (Wang et al. 2006). In contrast to the chemical routes, the enzymatic processes require mild reaction conditions and are gaining popularity in the chemical industry for the synthesis of commodity/fine chemicals. Ease of biocatalyst production, rate of enzyme activity, substrate, and product tolerance are the main factors 
considered for the commercialization of the enzyme based bioprocesses. The important requirement of a bioprocess is the starting material (substrate), which is either manufactured chemically or available from biotic sources.

Nitrilase mediated hydrolysis of nitriles has been explored by various workers for the synthesis of many pharmacologically important acids. The efforts of academia and industries made possible the utilization of nitrilases for the manufacture of various chiral acids otherwise difficult to produce through chemical route, viz. 5-hydroxypyrazine-2-carboxylic acid, 6-hydroxypicolinic acid, $(R)$-mandelic acid, $(R)$-3-chloromandelic acid, (R)-4-cyano-3- hydroxybutyric acid, and (S)-ibuprofen (Liese et al. 2000; Brady et al. 2004, Breuer et al,. 2004; DeSantis et al. 2003, Wang 2005, Sheldon et al. 2007, Xue et al. 2011).

The potential of fungal nitrilases (Aspergillus niger K10 and Fusarium solani O1) for the bioconversion of 4-CP to INA have been explored by Vejvoda et al. (2006) and Malandra et al. (2009). Isonicotinamide formed in the reaction catalyzed by the fungal nitrilase decreased the purity INA in the end, which was further hydrolysed to INA utilizing amidase from Rhodococcus erythropolis A4. A cascade of immobilized nitrilase and amidase was created for hydrolyzing 4-CP to INA (Vejvoda et al. 2006). Malandra et al. (2009) utilized the CLEAs (cross linked enzyme aggregates) of purified fungal nitrilases and bacterial amidase for developing CSMR (constant stirred membrane reactor) cascade for improving the purity of INA up to $99.9 \%$.

The nitrilases from the bacterial origin have been unexplored for hydrolysing 4-CP to INA, whereas its isomer 3-CP has been used as substrate for the synthesis of nicotinic acid (Mathew et al. 1988, Vaughan et al. 1989, Almatawah and Cowan, 1999, Prasad et al. 2007, Sharma et al. 2006, 2011). N. globerula NHB-2 harbours three nitrile metabolizing enzymes, viz., nitrilase, nitrile hydratase, and amidase (Sankhian et al. 2003, Bhalla and Kumar 2005). Nitrilase of N. globerula NHB-2 (NitNHB2) is selectively expressed in growth medium supplemented with isobutyronitrile or propionitrile (Bhalla and Kumar 2005, Sharma et al. 2006, 2011). The efforts for the synthesis of non chiral acids using nitrilases are limited in literature, and have been skewed towards synthesis of chiral acids of pharmaceutical importance in recent years (Sheldon et al. 2007, Liang et al. 2008, Novill et al. 2011, Xue et al. 2011, Pandey et al. 2011). Keeping in view that non chiral acid of pharmaceutical value are equally important, the NitNHB2 have been explored for the synthesis of nicotinic acid from 3-CP (Sharma et al. 2006, 2011). The NitNHB2 also showed $87 \%$ activity for $4-\mathrm{CP}$ hydrolysis with respect to 3-CP without forming isonicotinamide as intermediate. Thus, the present research work was undertaken to explore the potential of NitNHB2 for the synthesis INA from 4-CP. This is first report of utilizing bacterial nitrilase for the production of INA form 4-CP at a fastest rate.

\section{Materials and Methods Materials}

4-CP (99 \% pure) and INA was from Alfa Aesar, A Johnson Matthey Company (earlier Lanchaster Synthesis). The media components were procured from HiMedia, Mumbai (India). All the other reagents were of analytical or HPLC grade as per the requirement.

\section{Microorganism and culture conditions}

N. globerula NHB-2 (MTCC 6278) was isolated in the Department of Biotechnology, Himachal Pradesh University, Shimla (Bhalla and Kumar, 2005). Nitrilase of $N$. globerula NHB-2 was hyperinduced through multiple feeding of isobutyronitrile in the growth medium containing $1.0 \%$ glucose, $0.5 \%$ peptone, $0.3 \%$ beef extract, and $0.1 \%$ yeast extract ( $\mathrm{pH}$ 7.5) described previously (Sharma et al. 2011). After $30 \mathrm{~h}$ of incubation the cells were harvested by centrifugation at $8,000 \times \mathrm{g}\left(4^{\circ} \mathrm{C}, 5 \mathrm{~min}\right)$, and washed twice with $0.1 \mathrm{M} \mathrm{NaH} \mathrm{PO}_{4} / \mathrm{Na}_{2} \mathrm{HPO}_{4}$ buffer ( $\mathrm{pH}$ 7.5), finally resuspended in the same buffer (referred to as resting cells).

\section{Nitrilase assay}

If not otherwise mentioned, the nitrilase assay was performed in reaction mixture $(1.0 \mathrm{~mL})$ containing $0.1 \mathrm{M}$ $\mathrm{NaH}_{2} \mathrm{PO}_{4} / \mathrm{Na}_{2} \mathrm{HPO}_{4}$ buffer (pH 7.5), $50 \mathrm{mM} \mathrm{4-CP}$ and resting cells at $35^{\circ} \mathrm{C}$ in a water bath shaker. After $15 \mathrm{~min}$ of incubation, the reaction was quenched with equal volume of $0.1 \mathrm{~N} \mathrm{HCl}$.

\section{Analytical methods}

Quantitative estimation of 4-CP and INA in the assay mixture was performed through high pressure chromatography (HPLC) using series 200 Ic pump (Perkin Elmer) equipped with Inertsil ${ }^{\circledR}$ ODS-3 column $(5 \mu \mathrm{m}, 4.6 \times 150$ mm, GL Sciences, Japan) and 785A Programmable Absorbance Detector (Applied Biosystem). Chromatogram was monitored at $230 \mathrm{~nm}$ using mobile phase $(4: 1=10 \mathrm{mM}$ $\mathrm{KH}_{2} \mathrm{PO}_{4}, \mathrm{pH} 2.8$, adjusted with $\mathrm{H}_{3} \mathrm{PO}_{3}$ : acetonitrile) at a flow rate of $1.0 \mathrm{~mL}$ per min using NetWin Software (Netel Chromatographs, India). The calibration curves for 4-CP (2-20 mM) and INA (0.2-2.0 mM) was prepared.

One unit of nitrilase activity was defined as that amount of resting cells $\left(\mathrm{mg}\right.$ dry cell $\left.=\mathrm{mg}_{\mathrm{DCW}}\right)$ which catalyzed the increase of one micromole of INA per min by the hydrolysis of 4-CP under assay conditions.

\section{Production of isonicotinic acid from 4-cyanopyridine}

The optimization of reaction conditions to produce nicotinic acid using NitNHB2 showed stability of the 
enzyme at $35^{\circ} \mathrm{C}$ in $0.1 \mathrm{M} \mathrm{NaH} \mathrm{PO}_{4} / \mathrm{Na}_{2} \mathrm{HPO}_{4}$ buffer (pH 7.5) (Sharma et al. 2011). The other parameters for INA production were optimized in this study.

\section{Effect of 4-cyanopyridine on nitrilase activity}

Different concentrations of 4-CP ranging from 10 to 250 $\mathrm{mM}$ were added in the reaction to study the effect of substrate concentration on enzyme activity. The reaction was performed at $35^{\circ} \mathrm{C}$ for $15 \mathrm{~min}$. NitNHB2 hydrolysing activity in reaction containing $50 \mathrm{mM} 4-\mathrm{CP}$ at $35^{\circ} \mathrm{C}$ was used to gauge the biocatalyst units $(\mathrm{U})$ to be used in subsequent reactions.

\section{Time course of 4-cyanopyridine conversion}

NitNHB2 activity was inhibited at higher concentrations 4-CP, i.e. substrate inhibition effect was encountered. To achieve $100 \%$ hydrolysis of 4-CP, NitNHB2 (2.5, 5.0 and $\left.10 \mathrm{U} \mathrm{mL}^{-1}\right)$ was added to the reaction mixture $(2.0 \mathrm{~mL})$ containing $200 \mathrm{mM} 4-\mathrm{CP}$. The reaction was performed at $35^{\circ} \mathrm{C}$ and INA formed due to nitrilase activity was quantified every $10 \mathrm{~min}$ interval.

Fed batch reaction at $40 \mathrm{~mL}$ scale (200 mM 4-cyanopyridine feed/40 $\mathrm{min}$ )

Using $10 \mathrm{U} \mathrm{mL}^{-1}$ nitrilase activity in the reaction, $100 \%$ conversion of $200 \mathrm{mM}$ of 4-CP to INA was achieved in $40 \mathrm{~min}$. Thus fed batch reaction performed in $40 \mathrm{~mL}$ volume containing $10 \mathrm{U} \mathrm{mL}^{-1} \mathrm{NitNHB} 2$, and $200 \mathrm{mM}$ 4-CP (1.25 g) fed after every $40 \mathrm{~min}$ interval. A total of 10 feeds were added to the reaction, and sample was withdrawn before every feed for 4-CP and INA quantification.

Fed batch reaction at $40 \mathrm{~mL}$ scale (100 mM 4-cyanopyridine feed/20 $\mathrm{min}$ )

The feeding of $200 \mathrm{mM}$ 4-CP resulted in retardation of NitNHB2 activity after $3^{\text {rd }}$ feed. Thus, a lower level of substrate feeding $(100 \mathrm{mM})$ was applied at an interval of $20 \mathrm{~min}$ to achieve higher yield of INA. In 20 feeds, a total of 8.34 g 4-CP was added to the reaction mixture.

\section{Fed batch reaction at $1 \mathrm{~L}$ scale $(100 \mathrm{mM}$ 4-cyanopyridine feed/20 $\mathrm{min}$ )}

The above experiment resulted in $100 \%$ conversion of 4-CP to INA up to seventh feed after which the rate of substrate hydrolysis declined. This reaction was scaled up to $1 \mathrm{~L}$ in a 1.5 L BioFlow C-32 fermenter (New Brunswick Scientific, USA). The substrate corresponding to $100 \mathrm{mM}$ (10.41 g) was fed after every $20 \mathrm{~min}$. A total of $0.7 \mathrm{~mol}(72.9 \mathrm{~g})$ of 4-CP was added to the reaction mixture in seven feeds. The temperature of the reaction was maintained at $35^{\circ} \mathrm{C}$ and impeller speed was $200 \mathrm{rpm}$ for proper mixing of substrate and resting cells.

\section{Results}

The bacterial nitrilase has been for the first time utilized to develop biotransformation process for the production of INA from 4-CP. NitNHB2 activity profile against various nitrilase has been published in our pervious article (Sharma et al. 2011). The hyperinduced resting cells of N. globerula NHB-2 showed $5.71 \mathrm{U} \mathrm{mg}_{\mathrm{DCW}}^{-1}$ (87\% with respect to 3-CP) nitrilase activity for $50 \mathrm{mM} 4-\mathrm{CP}$ in reaction mixture at $35^{\circ} \mathrm{C}$. The nitrilase of $R$. rhodochrous $\mathrm{J} 1$ exhibited $79 \%$ activity $\left(0.72 \mathrm{U} \mathrm{mg} \mathrm{DCW}_{\mathrm{DCW}}^{-1}\right.$ ) for $4-\mathrm{CP}$ in comparison for activity against 3-CP (Mathew et al. 1988).

\section{Production of isonicotinic acid from 4-cyanopyridine Effect of 4-cyanopyridine on nitrilase activity}

Similar to the effect of 3-CP concentration on nitrilase activity (Sharma et al. 2011), at higher concentrations of 4-CP, inhibitory effect on the nitrilase activity of free cells was observed. Though nitrilase was able to tolerate higher concentrations of substrate there was steady decline of activity (Figure 1). The activity obtained at $50 \mathrm{mM}$ 4-cyanopyridine at $35^{\circ} \mathrm{C}(5.71 \mathrm{U}$ $\mathrm{mg}_{\mathrm{DCW}}^{-1}$ ) was used to gauge the amount of nitrilase units $(\mathrm{U})$ to be added in the subsequent reaction. Vejvoda et al. (2006) and Malandra et al. (2009) have used very low concentration of $4-\mathrm{CP}, 40 \mathrm{mM}$ and $50 \mathrm{mM}$ for producing INA, respectively.

\section{Time course of 4-cyanopyridine conversion}

The INA accumulation in the reaction containing 200 $\mathrm{mM}$ 4-CP is shown in Figure 2. The added substrate was completely converted to INA, in the presence 5.0 and $10.0 \mathrm{U} \mathrm{mL}^{-1}$ nitrilase activity within 60 and $40 \mathrm{~min}$, respectively. These results showed that $200 \mathrm{mM}$ feed at $40 \mathrm{~min}$ time interval could be used for fed batch reaction containing $10 \mathrm{U} \mathrm{mL}^{-1}$ nitrilase activity.

\section{Fed batch reaction at $40 \mathrm{~mL}$ scale (200 mM 4-cyanopyridine} feed/40 $\mathrm{min}$ )

In presence of $10 \mathrm{U} \mathrm{mL}^{-1} \mathrm{NitNHB} 2$ in the reaction and feeding $200 \mathrm{mM} 4-\mathrm{CP}$ at an interval of $40 \mathrm{~min}$, no substrate inhibition was observed till $2^{\text {nd }}$ feed (Figure 3 ). The rate of substrate hydrolysis declining to $86 \%$ during $3^{\text {rd }}$ feed, producing $172 \mathrm{mM}$ INA. In $4^{\text {th }}$ feed the conversion rate further retarded to $43 \%$ and only $86 \mathrm{mM} 4-\mathrm{CP}$ was hydrolysed. The rate of INA formation in $5^{\text {th }}, 6^{\text {th }}, 7^{\text {th }}, 8^{\text {th }} 9^{\text {th }}$ and $10^{\text {th }}$ feed with respect to the $1^{\text {st }}$ feed was $18,7,5,4,1$, and $0 \%$, respectively. A total of $0.729 \mathrm{M}$ INA was formed though a total of $2 \mathrm{M}$ 4-CP was fed. The substrate inhibition effect declined the NitNHB2 hydrolysing activity in this fed batch, leading to the reduction of the biotransformation productivity. 


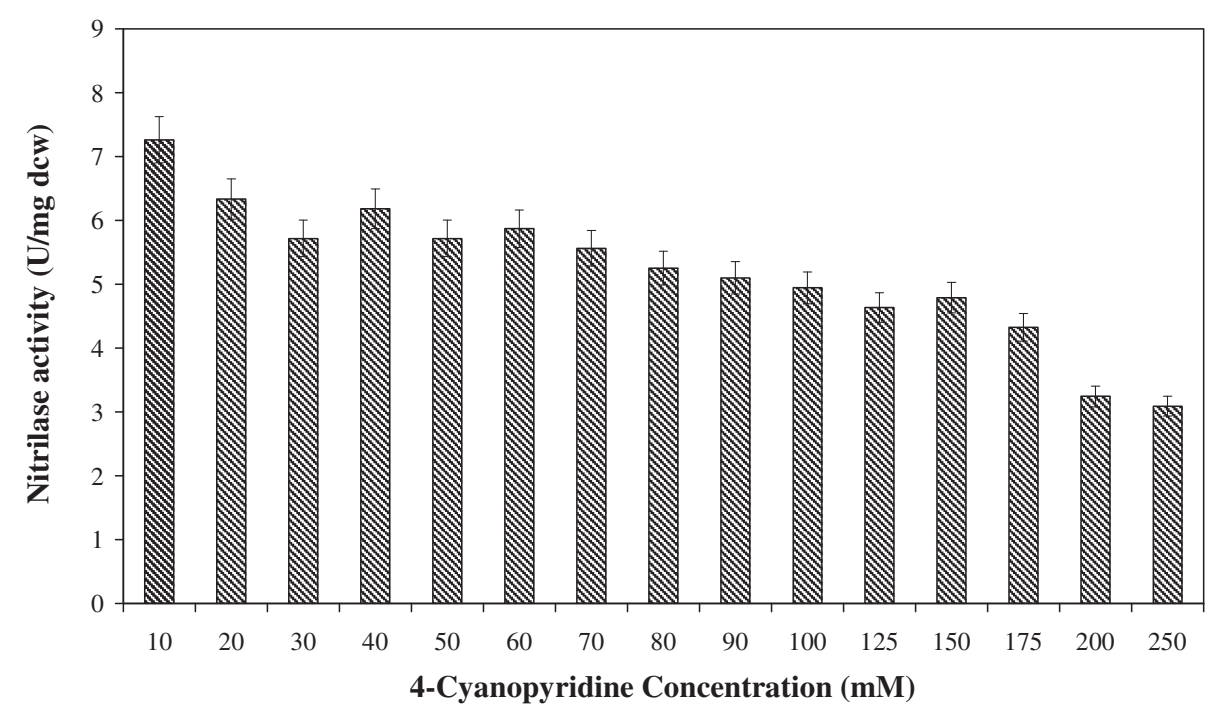

Figure 1 Effect of 4-CP concentration on nitrilase activity of $N$. globerula NHB-2.

Fed batch reaction at $40 \mathrm{~mL}$ scale (100 mM 4-cyanopyridine feed/20 $\mathrm{min}$ )

The accumulation of INA and 4-CP during $100 \mathrm{mM}$ substrate feeding is shown in Figure 4. The low level substrate feeding resulted in $100 \%$ conversion of $700 \mathrm{mM} 4-\mathrm{CP}$ to product in $2 \mathrm{~h} 20 \mathrm{~min}$ without affecting the rate of hydrolysis. A similar decline in the rate of 4-CP hydrolysis was observed with respect to previous fed batch, but at higher concentration of INA. In the $8^{\text {th }}$ feed the substrate hydrolysis rate declined to $60 \%$, reaching $10 \%$ in the $12^{\text {th }}$ feed and
$2 \%$ in the last feed. Only $258 \mathrm{mM}$ additional INA was formed though $1300 \mathrm{mM}$ 4-CP had been fed. Low level substrate feeding $(100 \mathrm{mM} / 20 \mathrm{~min})$ improved the productivity and no substrate inhibition was encountered till $7^{\text {th }}$ feed.

\section{Fed batch reaction at $1 \mathrm{~L}$ scale (100 mM 4-cyanopyridine/ $20 \mathrm{~min}$ )}

The time and space productivity of any bioprocess is its key feature, ruling the feasibility of its commercialization.

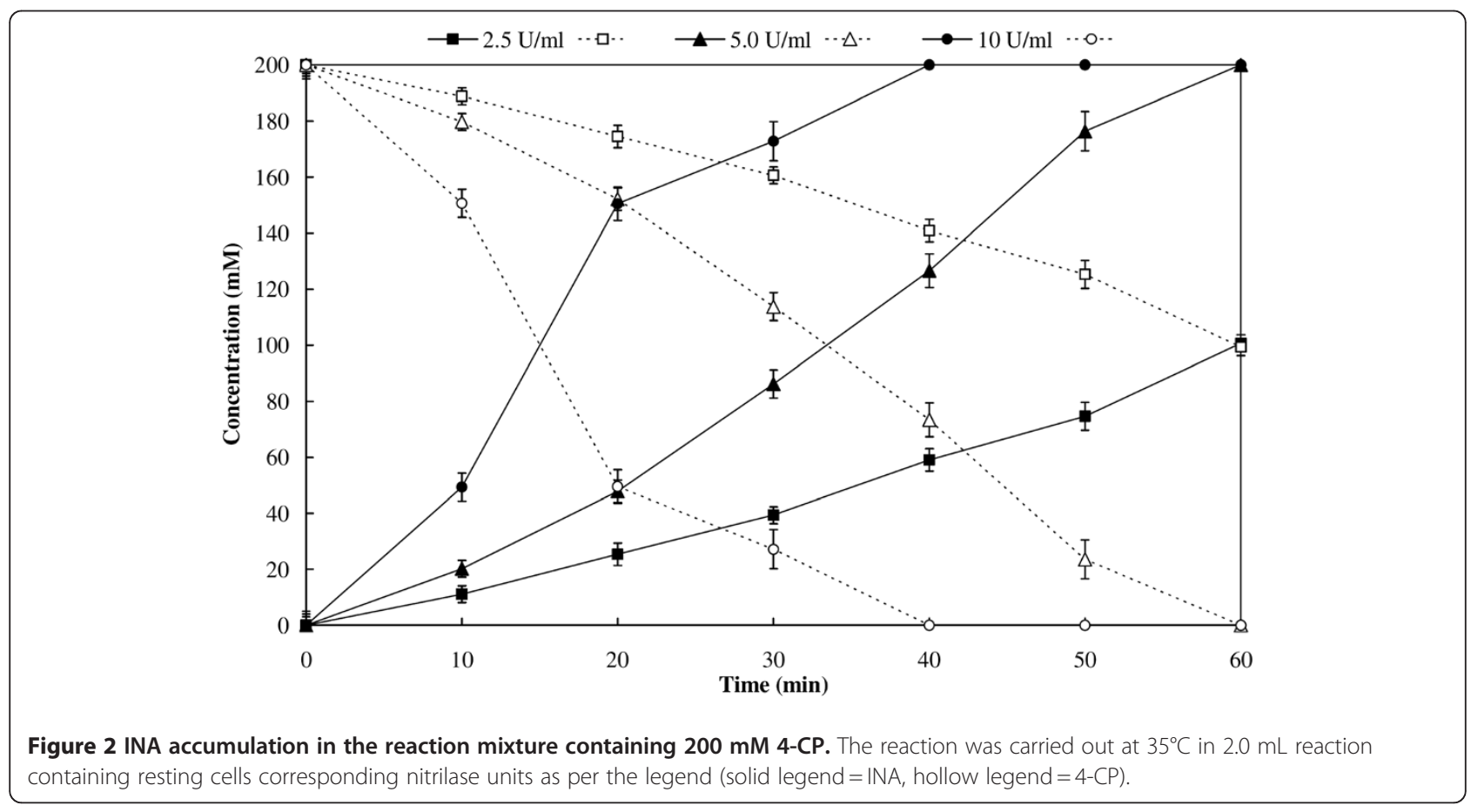




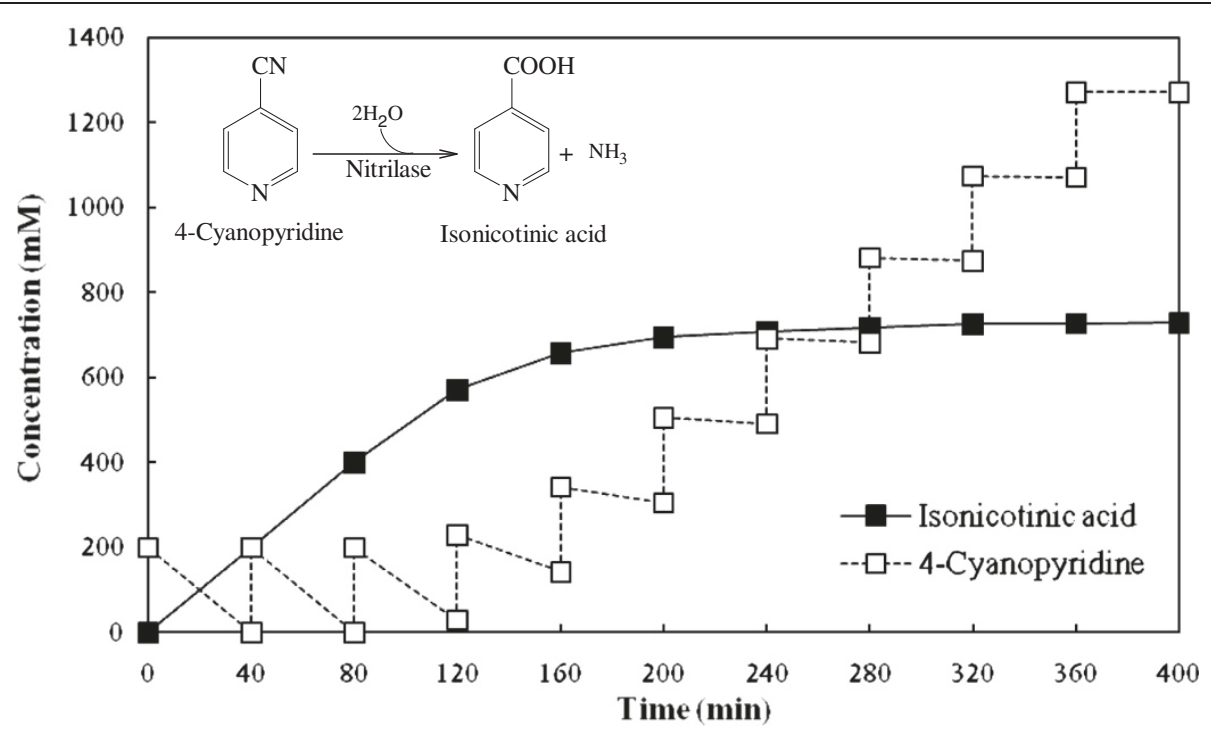

Figure 3 Accumulation of INA acid and 4-CP in $40 \mathrm{~mL}$ reaction mixture containing resting cells corresponding to $10 \mathrm{U} \mathrm{mL} L^{-1}$ nitrilase activity. Reaction was carried out at $35^{\circ} \mathrm{C}$ and $200 \mathrm{mM} 4$-cyanopyridine was fed at an interval of $40 \mathrm{~min}$.

The isonicotinic production process was scale up to $1 \mathrm{~L}$ (containing 1.75 $\mathrm{g}_{\mathrm{DCW}}$ corresponding to $10,000 \mathrm{U}$ nitrilase activity), resulting in $100 \%$ conversion of the added 0.7 mole 4-CP to INA in $140 \mathrm{~min}$ at a rate of $21 \mathrm{~g}$ INA $\mathrm{h}^{-1} \mathrm{~g}_{\mathrm{DCW}}^{-1}$. This biotransformation process is superior to the previously described processes by Vejvoda et al. (2006) and Malandra et al. (2009), which involved use of immobilization of fungal nitrilase and bacterial amidase. N. globerula NHB-2 nitrilase achieved the time and space productivity of $36 \mathrm{~g} \mathrm{~L}^{-1} \mathrm{~h}^{-1}$ INA which is almost 38 times higher than the above processes.

\section{Recycling of recovered cells}

The cells recovered from the $1 \mathrm{~L}$ fed batch reaction retained $86 \%$ of the nitrilase activity (4.92 $\mathrm{U} \mathrm{mg}_{\mathrm{DCW}}^{-1}$ ). These cells when used for a second fed batch reaction (40 $\mathrm{mL}$ ) successfully converted $700 \mathrm{mM}$ of 4-CP to INA in 2 h $20 \mathrm{~min}$. This showed that the nitrilase of $N$. globerula

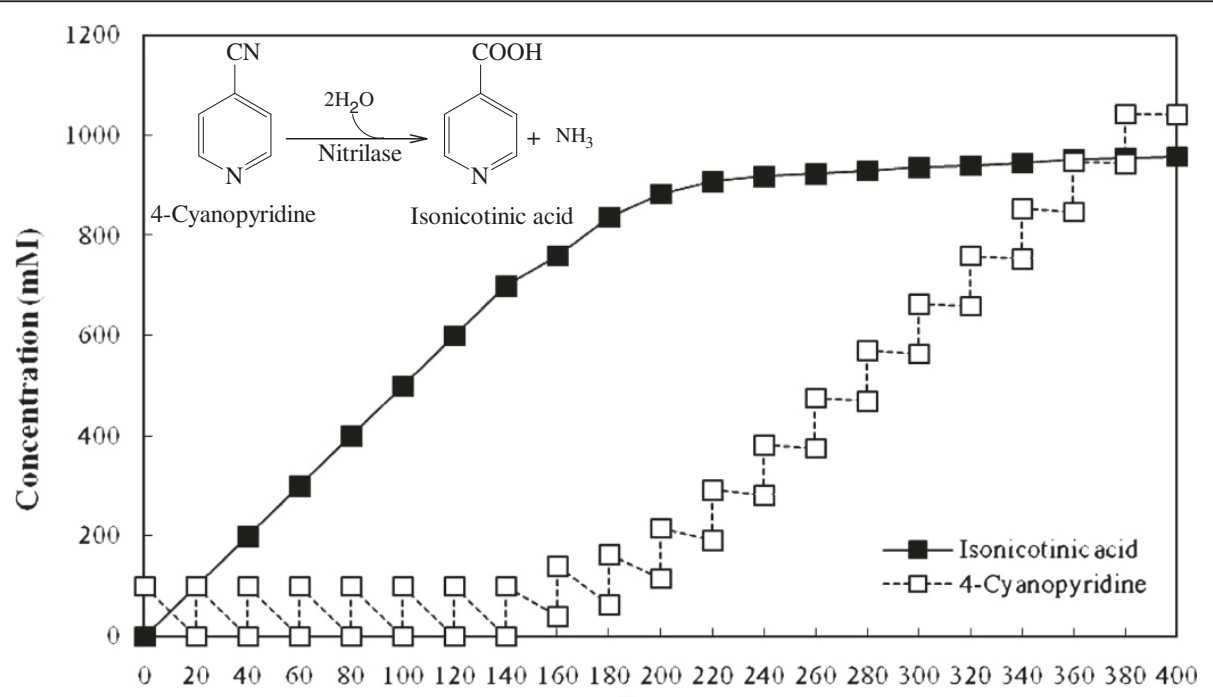

Time (min)

Figure 4 Accumulation of INA and 4-CP in $40 \mathrm{~mL}$ reaction containing resting cells corresponding to $10 \mathrm{U} \mathrm{mL}^{-1}$ nitrilase activity. Reaction was carried out at $35^{\circ} \mathrm{C}$ and $100 \mathrm{mM}$ 4-cyanopyridine was fed at an interval of $20 \mathrm{~min}$. 
NHB-2 was stable at $35^{\circ} \mathrm{C}$ and could be recycled through suitable immobilization techniques. Theoretically it was possible to utilize the recovered nitrilase to produce 0.6 moles of INA ( $86 \%$ of 0.7 moles). Thus, the total theoretical yield of INA through recycling the biocatalyst derived to be 1.3 moles $(0.7+0.6$ mole $)$.

\section{Discussion}

Nitrilase mediated conversion of nitriles to acids are gaining importance over the chemical routes, due to ease of biocatalyst production, mild reaction conditions, and formation of optically pure acids. In past decade, the search of nitrilases for optically active acids have gained importance for both academicians and industries (Liese et al. 2000, Brady et al. 2004, DeSantis et al. 2003, Breuer et al., 2004, Wang 2005, Sheldon et al. 2007, Xue et al. 2011, Novill et al. 2011, Pandey et al. 2011). The nitrilases also efficiently hydrolyse non chiral nitriles to acid adding advantage over the chemical routes of their synthesis (Mathew et al. 1988, Vaughan et al. 1989, Almatawah et al. 1999, Vejvoda et al. 2006, Luo et al. 2010, Malandra et al. 2009, Prasad et al. 2007, Raj et al. 2007, Sharma et al. 2006, 2011). The current research work was an attempt to explore the potential of $N$. globerula NHB-2 nitrilase for the synthesis of INA from 4-CP for the first time. Further, the study was focused on improving the biotransformation process and scaling up to one liter. Vejvoda et al. (2006) have used a cascade of immobilized fungal nitrilase $(5.5 \mathrm{U})$ and bacterial amidase $(5 \mathrm{U})$ on $1 \mathrm{~mL}$ Butyl Sepharose column and feeding of $40 \mathrm{mM}$ 4-CP (0.3 $\mathrm{mL} \mathrm{m^{-1 }}$ ) producing $3.102 \mathrm{~g}$ isonicotinic (99.8\% purity) in $35 \mathrm{~h}$ with time and space productivity of $94 \mathrm{mg} \mathrm{L}^{-1} \mathrm{~h}^{-1}$. In CSMRs cascade loaded with nitrilase $(6.5 \mathrm{U})$ and amidase (5 U) as cell-free extracts immobilized in CLEAs produced $3.36 \mathrm{~g}$ INA (99.9\%) in $52 \mathrm{~h}$ with the time and space productivity of $118 \mathrm{mg} \mathrm{L}^{-1} \mathrm{~h}^{-1}$ when $50 \mathrm{mM}$ 4-CP was pumped at the rate of $10.5 \mathrm{~mL} \mathrm{~h}^{-1}$ (Malandra et al. 2009). During optimization studies for developing nitrilase mediated biotransformation process using $N$. globerula NHB-2, substrate inhibition effect was encountered, which was partially overcome using low concentration substrate $(100 \mathrm{mM})$ feed. This improved the amount of product formation in comparison to high concentration substrate $(200 \mathrm{mM})$ fed batch. The biotransformation process developed using $N$. globerula NHB-2 nitrilase achieved the time and space productivity of $36 \mathrm{~g} \mathrm{~L}^{-1} \mathrm{~h}^{-1}$ INA which is almost 38 times higher than above reports. Further, the INA produced was free from isonicotinamide due to lack of hydrating activity of $N$. globerula NHB-2 nitrilase, which was common with the fungal nitrilases.

Since very few INA synthesising biotransformation processes has been documented, comparison with process developed for synthesis of its isomer nicotinic acid, would explain the advantage for current process.
The nitrilase mediated processes developed hitherto for the conversion of $\mathrm{N}$-substituted aromatic nitriles (cyanopyridines) have not been commercialized due to low substrate tolerance, low product yield and slower conversion rates. The inhibitory effect of $3-\mathrm{CP}$ at $0.3 \mathrm{M}$ and $0.4 \mathrm{M}$ was observed for the nitrilase of $R$. rhodochrous $\mathrm{J1}$ (Mathew et al. 1988). The nitrilase of Nocardia rhodochrous LL100-21 showed decline in the rate of 3-CP hydrolysis at $0.5 \mathrm{M}$ and above $0.6 \mathrm{M}$ formation of nicotinic acid completely inhibited (Vaughan et al. 1989). Further, productivity of nicotinic acid were very low, viz. R. rhodochrous J1 (2.29 g nicotinic acid $\left.\mathrm{h}^{-1} \mathrm{~L}^{-1} \mathrm{~g} \mathrm{dcw}^{-1}\right)$, Rhodococcus sp. NDB 1165 (8.86 g nicotinic acid $\mathrm{h}^{-1} \mathrm{~L}^{-1} \mathrm{~g} \mathrm{dcw}^{-1}$ ) (Mathew et al. 1988, Prasad et al. 2007). The free cells of $N$. rhodochrous LL100-21 and B. pallidus Dac521 immobilized in calcium alginate greatly reduced the nitrilase activity. The nitrilase of these microorganisms remained active for prolonged incubation and only $96 \mathrm{~g}$ nicotinic acid in $150 \mathrm{~h}$ at a rate of $0.53 \mathrm{~g}$ nicotinic acid $\mathrm{h}^{-1} \mathrm{~g}_{\mathrm{DCW}}^{-1}$ was produced by $N$. rhodochrous LL100-21 (Vaughan et al. 1989). Immobilized free cells of B. pallidus Dac521 produced $3.12 \mathrm{~g}$ nicotinic acid in $100 \mathrm{~h}$ at a rate of $0.104 \mathrm{~g}$ nicotinic acid $\mathrm{h}^{-1} \mathrm{~g} \mathrm{dcw}^{-1}$ (Almatawah et al. 1999).

The present study was an attempt to develop an efficient biotransformation process using $N$. globerula NHB-2 nitrilase for the synthesis of INA. In terms of time and space, the productivity of INA $\left(36 \mathrm{~h} \mathrm{~L}^{-1} \mathrm{~h}^{-1}\right)$ reported here is the highest. This process is more convenient involving simple fed batch reaction at $35^{\circ} \mathrm{C}$ in sodium phosphate buffer. The results of the immobilization studies would help to develop a suitable biotransformation process for efficient production of INA.

\section{Competing interests}

The authors declare that they have no competing interests.

\section{Acknowledgments}

The authors acknowledge the Council of Scientific and Industrial Research, New Delhi for financial support in the form of Senior Research Fellowship to Dr Nitya Nand Sharma and Dr Monica Sharma. The computational facility availed at Bioinformatics Centre, H P University is also duly acknowledged.

\section{Author details}

'Department of Biotechnology, Himachal Pradesh University, Summer Hill, Shimla 171005, India. ${ }^{2}$ Present Address: Division of Plant Protection, Central Potato Research Institute, Shimla 171005, India. ${ }^{3}$ Present Address:

Department of Biotechnology, Delhi Technological University, Delhi - 110042, India.

Received: 10 January 2012 Accepted: 26 April 2012

Published: 26 April 2012

\section{References}

Almatawah QA, Cowan DA (1999) Thermostable nitrilase catalysed production of nicotinic acid from 3-cyanopyridine. Enz Microb Technol 25:718-724

Arai M, Alavi Yl, Mendoza J, Billker O, Sinden RE (2004) Isonicotinic acid hydrazide: an anti-tuberculosis drug inhibits malarial transmission in the mosquito gut. Exp Parasitol 106:30-6

Bhalla TC, Kumar H (2005) Nocardia globerula NHB-2: A versatile nitrile-degrading organism. Can J Microbiol 51:705-708 
Brady D, Beeton A, Zeevaart J, Kgaje C, van Rantwijk F, Sheldon RA (2004) Characterization of nitrilase and nitrile hydratase biocatalytic systems. Appl Microbiol Biotechnol 64:76-85

Breuer M, Ditrich K, Habicher T, Hauer B, Keßeler M, Stürmer R, Zelinski T (2004) Industrial methods for the production of optically active intermediates. Angewandte Chemie International Edition 43:788-824

DeSantis G, Wong K, Farwell B, Chatman K, Zhu Z, Tomlinson G, Huang H, Tan X, Bibbs L, Chen P, Kretz K, Burk MJ (2003) Creation of a productive, highly enantioselective nitrilase through gene site saturation mutagenesis (GSSM). J Am Chem Soci 125:11476-11477

Liang L-Y, Zheng Y-G, Shen Y-C (2008) Optimization of $\beta$-alanine production from $\beta$-aminopropionitrile by resting cells of Rhodococcus sp. G20 in a bubble column reactor using response surface methodology. Proc Biochem 43:758-764

Liese A, Seelbach K, Wandrey C (2000) Industrial biotransformations. Weinheim, WILEY-VCH, pp 317-321

Luo H, Fan L, Chang Y, Ma J, Yu H, Shen Z (2010) Gene cloning, overexpression, and characterization of the nitrilase from Rhodococcus rhodochrous tg1-A6 in E. coli. Appl Microbiol Biotechnol 60:393-400

Malandra A, Cantarella M, Kaplan O, Vejvoda V, Uhnáková B, Štěpánková B, Kubáč D, Martínková L (2009) Continuous hydrolysis of 4-cyanopyridine by nitrilases from Fusarium solani $\mathrm{O} 1$ and Aspergillus niger K10. Appl Microbiol Biotechnol 85:277-284

Mathew CD, Nagasawa T, Kobayashi M, Yamada H (1988) Nitrilase-catalyzed production of nicotinic acid from 3-cyanopyridine in Rhodococcus rhodochrous Jl. Appl Microbiol Biotechnol 54:1030-1032

Nowill RW, Patel TJ, Beasley DL, Alvarez JA, Jackson E, Hizer TJ, Ghiviriga I, Mateer SC, Feske BD (2011) Biocatalytic strategy toward asymmetric $\beta$-hydroxy nitriles and $\gamma$-amino alcohols. Tetrahedron Lett 52:2440-2

Pandey AC, Durve AA, Pathak MS, Sharon M (2011) White biotech approach to synthesize mandelic acid using microbes and plants as a source of nitrilase. Asian J Exp Biol Sci 2:191-200

Prasad S, Misra A, Jangir VP, Awasthi A, Raj J, Bhalla TC (2007) A propionitrile-induced nitrilase of Rhodococcus sp. NDB 1165 and its application in nicotinic acid synthesis. World J Microbiol Biotechnol 23:345-353

Qiao QD, Yu DY, Liang HY (2000) Electrochemical synthesis of 4-picolinic acid from 4-methylpyridine. Fine Chem 17

Raj J, Singh N, Prasad S, Seth A, Bhalla TC (2007) Bioconversion of benzonitrile to benzoic acid using free and immobilized cells of Nocardia globerula NHB-2. Acta Microbiol Immunol Hung 54:79-88

Sankhian UD, Kumar H, Chand D, Kumar D, Bhalla TC (2003) Nitrile hydratase of Rhodococcus rhodochrous NHB-2: optimization of conditions for production of enzyme and conversion of acrylonitrile to acrylamide. Asian J Microbiol Biotech Env Sci 5:217-223

Scriven EFV, Toomey JE, Murugan R (1998) Pyridine and pyridine derivatives. In: Kroschwitz Jl, Howe-Grant M (eds) Encyclopaedia of Chemical Technology, vol 20, 4th edn. John Wiley \& Sons, New York, pp 1-44

Sharma NN, Sharma M, Kumar H, Bhalla TC (2006) Nocardia globerula NHB-2: Bench scale production of nicotinic acid. Proc Biochem 41:2078-2081

Sharma NN, Sharma M, Bhalla TC (2011) An improved nitrilase-mediated bioprocess for synthesis of nicotinic acid from 3-cyanopyridine with hyperinduced Nocardia globerula NHB-2. J Ind Microbiol Biotechnol 38:1235-1243

Sheldon RA, Arends I, Hanefeld U (2007) Green Chemistry and Catalysis. WILEY-VCH Verlag $\mathrm{GmbH} \&$ C, KgA, Weinheim

Vaughan PA, Knowles CJ, Cheetham PSJ (1989) Conversion of 3-cyanopyridine to nicotinic acid by Nocardia rhodococcus LL100-21. Enz Microb Technol 11: 815-823.

Vejvoda V, Kaplan O, Kubáč D, Křen V, Martínková L (2006) Immobilization of fungal nitrilase and bacterial amidase-two enzymes working in accord. Biocatal Biotransform 24:414-418

Wang M-X (2005) Enantioselective biotransformations of nitriles in organic synthesis. Topic Catal 35:117-130

Wang LC, Zhao JH, Song CY, Xu HS (2006) Studies on electrosynthesis conditions of isonicotinic acid from 4-methylpyridine. J Chem Eng Technol 22:372-375

Wu F, Huang ZQ, Hu NY (1991) Electrochemical synthesis of 4-picolinic acid. J Guang Dong Chem Eng 4:21-24

Xue Y-P, Xu S-Zh, Liu Z-Q, Zheng Y-G, Shen Y-C (2011) Enantioselective biocatalytic hydrolysis of ( $\mathrm{R}$, S)-mandelonitrile for production of (R)-(-)-mandelic acid by a newly isolated mutant strain. J Ind Microbiol Biotechnol 38:337-345
Yadav GD, Joshi SS, Lathi PS (2005) Enzymatic synthesis of isoniazid in non-aqueous medium. Enzyme Microb Technol 36:217-222

doi:10.1186/2191-0855-2-25

Cite this article as: Sharma et al: Nocardia globerula NHB-2 nitrilase catalysed biotransformation of 4-cyanopyridine to isonicotinic acid. AMB Express 2012 2:25.

\section{Submit your manuscript to a SpringerOpen ${ }^{\odot}$ journal and benefit from:}

- Convenient online submission

Rigorous peer review

- Immediate publication on acceptance

- Open access: articles freely available online

- High visibility within the field

- Retaining the copyright to your article

Submit your next manuscript at $>$ springeropen.com 